\title{
Dentists' Provident paid $98.9 \%$ of new claims in 2021
}

Dentists' Provident has paid out $£ 5.4 \mathrm{~m}$ to members in 2021, their latest figures show.

In another year affected by the COVID19 pandemic, Dentists' Provident has continued to support the dental profession by caring for its members impacted by illness or injury.

Their claims report for 2021 released today shows that Dentists' Provident paid $98.9 \%$ of new claims received compared to $96.3 \%$ in 2020.

The largest of the 1,190 claims paid in 2021 amounted to $£ 80,749$. The majority of the claimants were $46-55$ years-old, and in 2021 the younger workforce made up 9\% of Dentists' Provident's pay-out (aged under 35$)$. The youngest claimant was 26-years-old.

The report also shows that musculoskeletal disorders (24\%), psychiatric disorders (16\%) and accidents (15\%) were amongst the most significant reasons for claim.

Coronavirus related pay-outs totalled $£ 351,000$ in 2021 and made up nearly $70 \%$ of all infectious disease claims from members, who on average were off work for two weeks due to the virus.

Farrukh Mirza, CEO of Dentists' Provident, said: 'We know how the impact of the pandemic continues to be felt by dental professionals in their daily lives. Many are still working tirelessly to catch up, while facing more worries, illness and financial uncertainty from restrictions in the way they practice. This past year, our members have shown incredible resilience despite the longevity of the ongoing situation. By being flexible, approachable and supportive, we have tried to be one of the few things in their lives that have not become more complicated as a result of the pandemic.'

Simon Elliott, Chief Risk Officer added: 'We take pride in our personalised and thorough underwriting, giving members confidence they have a dependable income protection plan that works for them. We have always had a low number of complaints. Last year we saw an even further drop in these, with just two claims related complaints. We have not lost a single referral to the Financial Ombudsman Service in the last five years and that is a testament to the quality of our people and our processes.'

To read the full '2021 Claim statistics' report visit www.dentistsprovident.co.uk/ media/1761/claims-stats-2021.pdf.

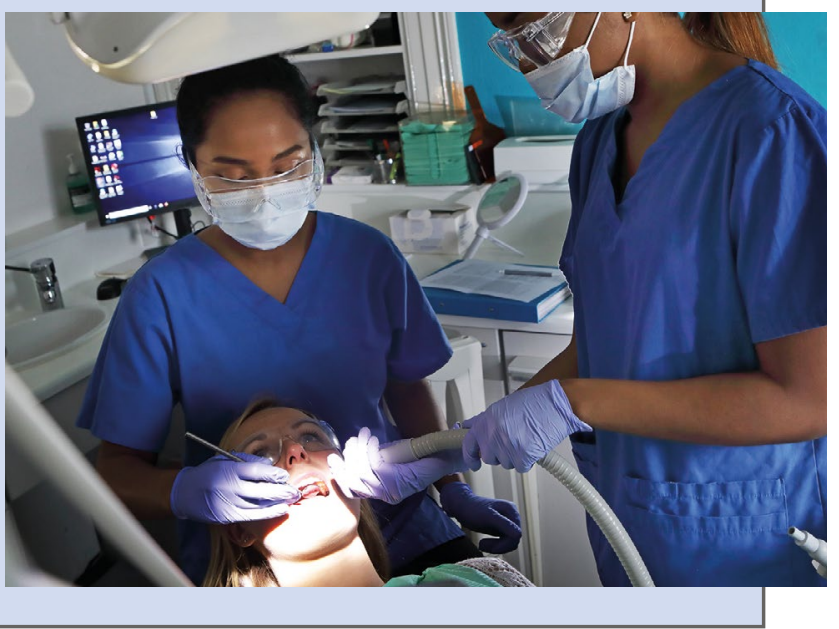

\section{Rattan successfully fights vicarious liability claim at Court of Appeal}

Dental Protection member Mr Raj Rattan has successfully challenged a vicarious liability claim at the Court of Appeal - an outcome that will benefit many practice owners in England and Wales.

The claim was brought by a client of the Dental Law Partnership (DLP) for treatment carried out by associate dentists at $\mathrm{Mr}$ Rattan's former practice - Mr Rattan did not carry out any of the patient's treatment.

Mrs Hughes, represented by DLP, pursued a claim against Mr Rattan under both vicarious liability and non-delegable duty of care, despite the fact that the treating dentists had been identified and remain willing to respond to the claim. DLP and their client refused to engage with them and instead pursued Mr Rattan as practice owner.

The Preliminary Hearing judgment in July 2021 made clear that Mr Rattan's conduct as a practice owner was not being criticised, however it ruled that he was vicariously liable for the self-employed associate dentists working at his former practice, and that he owed Mrs Hughes a non-delegable duty of care when she attended his practice for dental treatment.

Geoff Jones, Executive Director, Member Protection and Support, at Dental Protection said: 'We have supported Raj Rattan as a Dental Protection member in fighting this case which has significant repercussions for the dental profession. We are extremely pleased the judgment on vicarious liability has not been upheld, and will now explore whether we can take the fight on nondelegable duty of care to the Supreme Court.

'These mostly unnecessary claims cause real distress for practice owners, some of whom have long since retired, and pose a risk to the long-established arrangements that exist between practice owners and their associates.

'The self-employed dentists who were involved in the patient's care were willing to respond to the claim from the outset, but DLP and their client refused to engage with them. Mrs Hughes had nothing to gain by refusing to engage with the treating dentists and pursuing Mr Rattan personally.

'DLP has been pursuing a number of claims like this against the practice owner rather than the self-employed dentists who provided the treatment. In the majority of those cases, where a liability was established, the treating dentists are also willing to settle and the claimant could have received compensation much sooner.

'Now, due to the Court of Appeal decision in this case, many of these vicarious liability claims brought by DLP on behalf of their clients, may fail unless it can be shown that the practice owed them a non-delegable duty of care in relation to the treatment carried out by the treating dentists.

'We are carefully considering the implications of the Court's finding in relation to non-delegable duty of care and will provide further guidance to practice owners as soon as possible.' 